\title{
FACTORS AFFECTING CURRENT ACCOUNT BALANCE OF TURKEY: A SURVEY WITH THE COINTEGRATING REGRESSION ANALYSIS
}

DOI: 10.17261/Pressacademia.2015414533

\section{Gokhan Ozdamar ${ }^{1}$}

1Süleyman Demirel University, Turkey. Email: gokhanozdamar@sdu.edu.tr

Keywords
Current account
balance,
Turkey,
Johansen
cointegration,
cointegrating
regression analyses

JEL Classification F32; F41

\begin{abstract}
In Turkish economy, especially in recent years, ratio of current account deficits to national income is considerably high. Interrelations between current account balance and other macroeconomic indicators make it important to investigate which factors to what extent affect the current account balance in terms of economic policy decisions. In this study, the relationships between current account balance and various macroeconomic variables in Turkish economy are investigated empirically with Johansen cointegration test and with cointegrating regression analyses (FMOLS, CCR and DOLS) for the 1994-2014 period. It is found that foreign trade balance is a strong explanatory of the current account balance; terms of trade and gross domestic product also have statistically significant effects on the current balance. According to the results Harberger-Laursen-Metzler (HLM) hypothesis seems to be valid for Turkey. Besides, results of the study reveal that domestic interest rates and real effective exchange rate affects Turkey's current account balance as expected but these variables are found to be insignificant.
\end{abstract}

\section{INTRODUCTION}

Ensuring external economic balance, meaning the balance of foreign exchange in-flows and out-flows, is as important for the stability of macro economy as the internal balance of a country meaning price stability, full employment and in this context growth targets. One of the main indicators concerning the external economic balance is current account balance component of the balance of payments. In this sense, the persistence of current account deficits is seen as one of the most crucial economic problems, especially in developing countries. Large current account deficits imply various risks for an economy and may cause the effects of economic crisis or fluctuations to deepen. Although there is no consensus among economists on whether a certain amount of current account deficit ratio can be accepted as a signal for an economic crisis or not, there is one on that high 
level of current deficits make the economy more vulnerable to crisis ${ }^{1}$. The importance of the current account deficits problem holds the subjects of determining the factors affecting current deficits and the sustainability (financing) of current deficits on the agenda of economists. Especially in developing countries, current account deficit is seen among the fundamental causes of instability in the economy. In recent years, compared to the current account deficit ratios of developed and emerging countries and previous figures for Turkey, it is agreed that Turkey's current account deficit is beyond the sustainable level and generates a risk factor for economic stability.

On the other hand, in order to determine the economic policies to be applied for removing the balance of payments disequilibrium and ensuring the sustainability of current account deficits, it is crucial to identify the factors affecting the current account balance. Potential effects of the policies intended for controlling current deficits on economic growth necessitate determining the factors affecting current account balance and effect levels of these factors on current account balance. In this context, the relationships of the current account balance in Turkish economy with foreign trade balance, gross domestic product, terms of trade, real effective exchange rates and domestic interest rates are examined in the study by utilizing 1994:Q1-2014:Q4 quarterly data with KPSS unit root test, Johansen cointegration test and with cointegrating regression (FMOLS, CCR and DOLS) analyses.

\section{THEORETICAL DISCUSSIONS ON THE CURRENT ACCOUNT DEFICITS}

Current account deficit is regarded as the broadest definition of the foreign trade deficit. Various factors may have direct or indirect effects on current deficits. Income or economic growth rates, budget deficits, foreign trade balance, terms of trade, exchange rates, interest rates, changes in total credit and deposit (saving) volumes, money supply or total money stock, inflation rates, internal-external debts and national/global crisis may be considered as the main factors affecting current deficits. Beside these variables, structural factors such as low level of production technology, import-dependent production and export structure, low level of domestic savings in the country are also seen as the main factors causing current deficits.

\footnotetext{
${ }^{1}$ It is seen in various studies in the economics literature that direct relationships are established between current deficits and economic crisis, and in some of these studies critical "current account deficit-to-GDP(gross domestic product)" ratios are calculated in terms of current account balance sustainability or its relationship with economic crisis. According to Dornbusch, a current account deficit-to-GDP ratio equivalent to $4 \%$ would be a crisis alarm for an economy. Similarly, many economists like Fischer state rising current deficits, current deficits expected to rise or unsustainable current deficits are precursors/triggers of economic crisis (see Uygur, 2012; Uygur, 2001). On the contrary, Edwards shows in his study that whether high levels of current deficits would cause exchange rate crisis or not varies with the extent of the description of crisis and the sample of analysis, and also shows that each and every high level of current account deficits does not cause an economic crisis (see Edwards, 2001).
} 
There are numerous approaches for explaining current account balance in economic theory. Classical economics attaches importance to the relationship between changes in money supply and general level of prices (quantity theory of money) for balance of payments adjustment. This approach is basically based on international gold-currency standard system (and therefore foreign exchange rate fluctuations). Another theory for explaining external balance is the elasticity approach. According to the theory, the removal of an external imbalance through exchange rate and price mechanism depends on the Marshall-Lerner condition (the sum of the export and import elasticity should be greater than 1 in absolute terms). According to the Monetarist approach, external imbalances are the result of money supply-demand imbalances. According to Keynesian income and expenditure (absorption) theory, the source of external imbalances is the expenditures exceeding domestic production (income), i.e. budget deficits or expansionary fiscal policies. The Mundell-Fleming model which was built on Keynesian approach and developed in the 1960s, has applies the IS-LM model on a free capital movement-open economy through extending it with the balance of payments (BP). According to the model, both the monetary and fiscal policies can be utilized for affecting external balance target. For explaining external balance, Mundell-Fleming model pays attention on the difference between domestic and foreign interest rates (Seyidoğlu, 2009). According to the Mundell-Fleming model, increased public deficits affects external balance through goods market (real exchange rate and disposable income) and capital account (real interest rate) (Papadogonas and Stournaras, 2006; Corsetti and Müller, 2006).

In parallel with the increased capital mobility and economic fluctuations till the 1980s, discussions on the sustainability of current deficits and the effects of currents deficits on economic crises have become prominent. Within this scope, the current deficit discussions have taken on an inter-temporal and dynamic dimension and started to be explained through a resolution process based on optimization. According to this approach, the determined optimum current deficit is compared with the realized current deficit and in case of a deficit over optimum level, an intervention is deemed necessary. Inter-temporal optimization approach foresees a robust positive relationship between savings and current deficit, but a robust negative relationship between investments and current deficits (Uygur, 2012). On the other hand, coexistence of budget and current account deficits in the 1980s in United States has put forward the twin deficits hypothesis. In addition to this, coexistence of budget and current account deficits with savings gap is called as triple deficit hypothesis in the literature.

Policies applied for accelerating economic growth could cause current deficits to become permanent and to be continuous. In a situation where technology, production and export levels are relatively low in a country, factors such as continuous increase in imports of technology, intermediate goods and investment goods parallel to the growth and industrialization policies, increasing imports of consumption goods in this process through increasing income, and on the contrary non-increasing or even gradually decreasing export-import ratios causes current deficits to become permanent by generating an import-dependent growth. Import-dependent growth and persistence of current deficits compel the economies of developing countries to be vulnerable to economic and financial 
instabilities. While the decreases in the value of national currencies due to national or global economic/political developments make it difficult to finance current deficits, the acceleration of capital outflows following increased ricks affects macroeconomic balances such as growth, inflation, interest rates, employment and refinancing of external debts negatively as a whole. Therefore, high level of current account deficits is a crucial indicator to pay attention as it has the risk to create a domino effect in economy at crisis periods.

Another point presenting the importance of current account deficit for economies is the expectation of high fragility in an economy against economic, financial or political developments or crises in the case of significantly high current account deficit-to-GDP ratio. The capacity of a country to endure existing economic balances against potential external funding cuts refers to the fundamental framework of economic fragility. One of the indicators paid attention in economic/financial fragility indices is the current account deficits or the current account deficit to GDP ratio ${ }^{2}$. Besides, it is stated that the common ground of Turkey, Brazil, India, Indonesia and South Africa, stated as the "fragile five", is their high, increasing and permanent current deficits which further turn these countries dependent to foreign capital flows ${ }^{3}$.

\section{CURRENT ACCOUNT DEFICIT PROBLEM OF TURKEY}

Turkish economy has had continuous foreign trade deficit annually since $1947 .{ }^{4}$ With the impact of foreign trade deficits it is observed that current account deficits of Turkey are structurally continuous in time. Although decreases in total consumption and imports especially during the economic crises periods temporarily affect current balance positively, current deficits persist in the subsequent periods.

Higher growth rates of imports than the ones for the exports excepting crises periods, gradually lead to increases in foreign trade deficits. High level of the growth rate of imports is considered to be the result of the import dependence of production and exports in Turkish economy. Thus, if the exports and imports according to the classification of commodity groups' data $^{5}$ are analyzed, it is seen that imports consist of raw materials and intermediate goods to a large extent while as the industrial goods take the first place in exports, thus an import based production and export structure prevails in Turkey.

Due to the increases in the external debts of Turkey and in foreign capital inflows, mainly through hot money, Turkish Lira (TL) has overvalued after 2001 and foreign trade deficits

\footnotetext{
${ }^{2}$ One of the indicators in the fragility index of the American Federal Reserve's (FED) Monetary Policy Report (February, 2014) is the ratio of current deficits to GDP. The result of the index shows that among 15 developing countries examined in the index, Turkey would be affected from decisions of the FED at most (see FED, 2014).

${ }^{3}$ See Morgan Stanley (2013).

${ }^{4}$ See Central Bank of the Republic of Turkey (2015a), Balance of Payment Statistics.

${ }^{5}$ See Turkish Statistical Institute (2015a), Foreign Trade by Classification of Broad Economic Categories.
} 
have increased. As tourism revenues and inflow of workers' remittances reduces the deficits partially, the current account deficits have increased extremely (Ertuna, 2007). The main causes of current account deficit in Turkish economy are seen as overvalued TL and economic growth, but it is understood that the effect of overvalued TL is relatively more severe (Kasman et al., 2005). Hot money inflows induced by high real interest rates makes TL overvalued against foreign currencies through creating an abundance of foreign exchange currency in the money market of Turkey. Foreign exchange abundance caused by speculative capital inflows leads to foreign trade and current account deficits by stimulating imports (Yeldan, 2005). Therefore an appreciation of TL affects the exports (and also the tourism revenues ${ }^{6}$ ) negatively, whereas by encouraging particularly consumption goods and investment goods imports leads to increasing growth of foreign trade deficits and hence current account deficits ${ }^{7}$.

As a result of high interest rate policy followed in Turkey in the 2000s, foreign capital inflows increased, furthermore the environment of confidence ensured by rapid growth and decreased inflation rate supported the growth through increasing consumption and investment expenditures but savings decreased at the meantime. High interest rate and overvalued TL policy was continued for a long time with the influence of the growth in the world economy. While valued exchange rate policy pleased both industrialists due to the production structure based on import of inputs and intermediate goods, and foreign investors due to the high returns on the transfer of profits, it also supported the Central Bank's inflation-targeting due to the economic structure utilizing significant rate of external inputs (Baydur, 2012).

Turkey's current account deficits in 2013 and 2014 were approximately 64.6 and 46.5 billion U.S. Dollars (USD), respectively. If the current account balance of Turkey is analyzed by years, it is seen that current deficits have been continuous since 2002 and had a rising trend excluding the years 2009, 2012 and 2014. On the other hand, Turkey's foreign trade and current account balances made progress with the high depreciations in TL following the economic decisions of the Turkish government in 1994, Russian economic crisis in 1998, and Turkish economic crisis in 2001.

Following the global financial crisis and the European debt crisis, with the effect of the decrease in imports caused by the contraction in domestic production parallel to the contraction in world markets, improvements in foreign trade and current account balances were observed in 2009, 2012 and 2014. On the other hand, the parallel course of foreign trade balance and current account balance reveals that the fundamental factor determining the current deficit in Turkish economy is the foreign trade (merchandise trade) deficit (see Fig. 1).

\footnotetext{
${ }^{6}$ Kara et al. (2012) show that there is a causality relationship from foreign exchange rates to tourism revenues in Turkey.

${ }^{7}$ For a study asserting the causes of the problem of current account deficits in Turkey as the policies of high real interest rate - low foreign exchange rate (overvalued TL) and as the growth models based on short term foreign capital inflows see Subaşat (2010).
} 
Figure 1: Current Account Balance and Foreign Trade Balance of Turkey (USD, million)

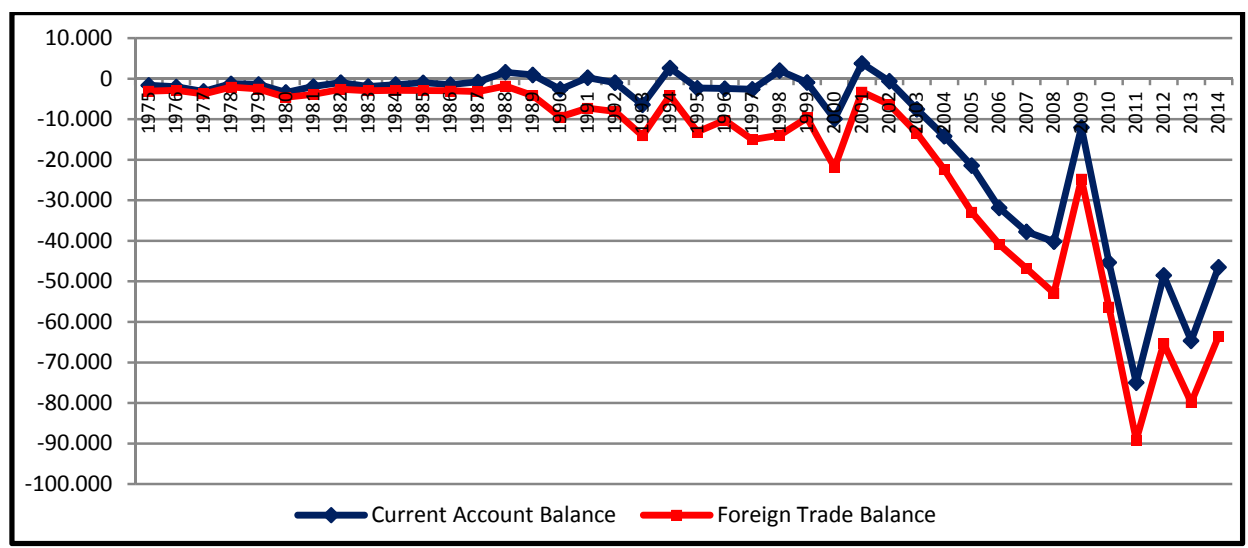

Source: Composed from the data of Central Bank of the Republic of Turkey (2015a). (*Data for 2014 is provisional.)

Since 2005 (except for 2009), the current account deficit-to-GDP ratio in Turkish economy has remained consistently above $4 \%$ critical value which is accepted as a risk level in terms of economic crises by some economists such as Dornbusch. Considering the 1980-2013 period, polynomial trend-line exhibited that the current account balance-to-GDP ratio shows a steady downward trend after 1994 until 2012, but after 2013 the trend-line shows an upward trend despite the ratio is still very high. The current account balance-toGDP ratio which has a simple average of $-2.42 \%$ in $1980-2014$ period, reached its highest negative level with the ratio of $-9.7 \%$ in 2011 during the European debt crisis ${ }^{8}$. One year before 1994 and 2001 economic crisis (i.e. in 1993 and 2000), the current account deficitto-GDP ratio reached high values with the significant impact of hot money (high interest rates-low exchange rate, valued Turkish Lira) policy. In contrast, in the economic crisis years of 1994 and 2001 it is seen that current account surplus was given with the effect of devaluations and the implementations of economic stabilization packages aiming to tighten the markets (see Fig. 2).

In the 2002-2014 period, simple average of the current account deficit-to-GDP ratio was realized as $-5.06 \%$. On the other hand, excluding 2009- Turkish economy achieved real growth compared to the previous year continuously during 2002-2014 periods. Considering the annual growth rates of 2002-2014 periods, simple average growth rate of

${ }^{8}$ Ratios are calculated from the data of IMF (2015), World Economic Outlook Database-October 2015. 
real GDP was 4.9\%. When 2002 and 2014 are taken as the beginning and ending period, the annual compound growth rate of real GDP was $4.72 \%{ }^{9}$

It is remarkable that real GDP growth and current deficit to GDP ratio were about $5 \%$ level in a similar manner, and this situation gives the idea that there might be a relationship between current deficit problem and economic growth in Turkish economy.

\section{Fig. 2: Ratio of Current Account Balance to GDP in Turkey (Percent)}

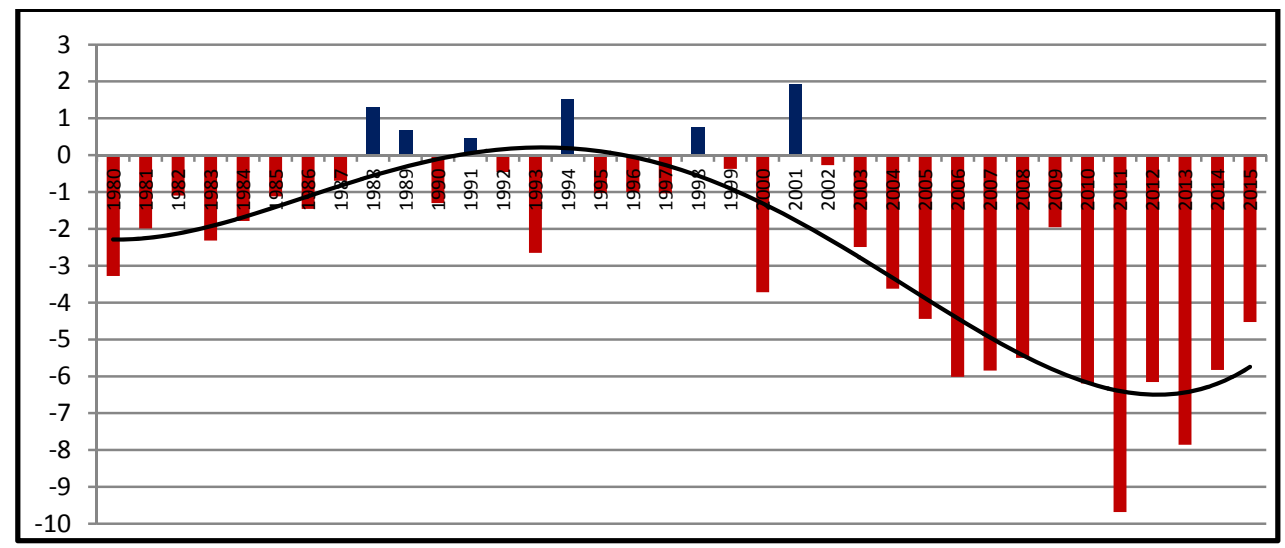

Source: Composed from the data of International Monetary Fund (2015) and World Economic Outlook DatabaseOctober 2015. (*Data for 2015 is estimation.)

In the literature, growth rate and exchange rate comes to the forefront as the main factors that determine current account deficit. In the studies on Turkish economy, whether the increase in demand resulting from growth or overvalued Turkish Lira caused by hot money inflows is more effective on current account deficits is a subject of discussion. While some economists regard high economic growth following the 2001 economic crisis as the main cause of current deficits, others defend that exchange rates determine the current account deficits with a delay under the effect of short-term capital movements (Erbaykal, 2007).

Apart from growth, foreign trade deficit and overvalued national currency other remarkable specific factors affecting current deficits of Turkey are dependence on foreign energy sources and increasing energy prices, low rate of domestic savings, high level of external debt stock, income transfers of foreign direct investments, periodic expansionary monetary/fiscal policies (Göçer, 2013). Turkey's import of petroleum products constitutes

\footnotetext{
${ }^{9}$ Ratios are calculated from the data of IMF (2015), World Economic Outlook Database-October 2015 and Turkish Statistical Institute (2015b), Main Statistics (National Accounts, GDP by production approach).
} 
significant share of her total import. ${ }^{10}$ In this regard, it is possible to say that one of the main reasons of Turkey's current deficits is dependence of petroleum products imports.

\section{LITERATURE REVIEW}

In economic literature, there are numerous studies on the determinants of the current account balance. Significant part of these studies is related to developing countries which experience current deficit problems. One of the main variables frequently focused in the studies on determinants of the current account balance is the balance of foreign trade (merchandise trade). As significant part of the current deficits especially in developing countries stems from high level of imports, empirical studies on current account include foreign trade deficit as a variable. In their study on the subject in the axis of Turkey, Canıdemir et al. (2011) obtain that an increase in imports increases current deficit while an increase in exports decreases it. In another study on Turkey, Göçer (2013) concludes that $37 \%$ and $26 \%$ of current deficit result from energy imports and non-energy foreign trade deficit, respectively. The result of the study by Erdogan and Bozkurt (2009) that investigates the relations among current deficit and a number of economic variables reveals that the highest correlation value belongs to the ratio of exports to imports. According to the study of Javaid and Raza (2013) on Pakistani economy, there is a positive relationship between current deficit and foreign trade deficit in the short-term and also there is a unidirectional causality from current deficit to foreign trade deficit. According to another survey on Pakistan made by Gulzar et al. (2007), a strong and positive long-term relationship exists between current account balance and foreign trade balance. In her study on the factors affecting the current account balance for the Russian economy Ketenci (2010) concludes that the current account balance is significantly affected more from commercial and financial variables in the long-term than the price of natural resources.

One of the subjects frequently discussed in the studies related to the factors affecting current account balance is the terms of trade. Gacaner Atış and Saygılı (2014) conclude that the most significant determinants of current deficit in Turkey are the terms of trade and the growth rate, and there is also a unidirectional causality from terms of trade to the current account deficit-to-GDP ratio variable. In their study on Turkey, Oktar and Dalyancı (2012) found a cointegration relationship in the long-term from terms of trade to current account balance. Hence, deterioration in trade would affect current account deficit in Turkish economy negatively. According to the study made by Erkılıç (2006), direction of the relationship between foreign trade and current account deficit in Turkish economy is uncertain.

\footnotetext{
${ }^{10}$ Ratio of the import of petroleum products to total import (in US Dollar) for various years are as follows: $12.8 \%$ in $1995,17.4 \%$ in $2000,12.5 \%$ in $2005,7.9 \%$ in 2010 and $8.1 \%$ in 2014 (Ratios are calculated from the data of Turkish Statistical Institute (2015a, 2015c)).
} 
According to the study of Aristovnik (2008) on Eastern European and CIS countries, deterioration in the terms of trade causes current account deficit to enlarge. In the same vein, in their studies on 9 developing countries Bayraktutan and Demirtaş (2011) utilize panel data analysis and identify that an improvement of the terms of trade reduces current deficit. Tagliabue (2005) concludes in his study on Italy that current deficit and terms of trade are associated in both short and long terms but the argument that the terms of trade causes the current account deficit is not supported for the period of 19922001. The results of the study of Chinn and Prasad (2003) which comprises 18 industrialized and 71 developing countries reveals that the volatility of the terms of trade is significantly and positively related with current account balance in terms of developing countries except for Africa, but negatively for industrialized countries. Bouakez and Kano (2008) analyze the effect of the terms of trade on current account balance in terms of the Harberger-Laursen-Metzler (HLM) effect for three different countries. The results of the study reveal that the changes in the terms of trade do not affect current account balance significantly, and the terms of trade shocks are not significant in explaining the changes in the current account balance for two out of three countries examined. Otto (2003) examines the presence of traditional HLM effect for 55 small open economies. According to the findings of the study, in the majority of the countries examined the primary effect of a positive shock in the terms of trade is an improvement in the trade balance. Therefore, according to the study the improvements in the terms of trade would affect current account balance positively.

The exchange rate effect is another subject frequently emphasized in empirical studies on the determinants of the current account balance. If the studies on Turkish economy are examined, it is seen that in general significant relationships are detected between exchange rates and current deficit. According to Erkılıç (2006), the most important determinants of the current account deficit in Turkish economy are previous current deficit, GDP growth rate and real exchange rate. According to empirical results of the research of Peker and Hotunoğlu (2009); real exchange rate, real interest rate and ISE-100 index are the most important factors affecting the current account deficit.

The findings of the study of Uz (2010) presents that exchange rate variable has the strongest effect on the current account balance but the improvement of the current account balance is associated with an appreciation of national currency in the short term whereas associated with depreciation in the long term. According to aforementioned study of Gacaner Atış and Saygılı (2014), in Turkish economy there is a unidirectional causality relationship from real exchange rate to the current account balance-to-GDP ratio. The findings of the mentioned study of Canıdemir et al. (2011) assert that the increase in the real exchange rate increases the current deficit in Turkey. Similarly, in his study Kayıkçı (2012) concludes that appreciation of the real exchange rate would lead to the deterioration of current account balance in Turkey. In the study of Erbaykal (2007), exchange rate and economic growth are determined as the causes of the current deficit, while no causality from exchange rate and the current account deficit towards economic growth is found. 
According to the panel VAR analysis of Kesikoğlu et al. (2013) for 28 OECD countries, exchange rate does not have any effect on current account deficit. On the other hand, according to the study of Das (2012) on developed, emerging and developing 106 countries; while current account balance has a positive relationship with exchange rate stability and has a negative relationship with real effective exchange rate in terms of developed countries, for emerging economies it has a negative relationship with exchange rate stability. According to aforementioned study of Aristovnik (2008), appreciation of the real exchange rate causes deterioration in current account balance. In their study on Pakistani economy Javaid and Raza (2013) determine a positive relationship between exchange rate and the current account deficit in the long term and also bidirectional causality between exchange rate and the current account deficit.

In terms of the importance of their effects on the current account balance, another variable which is frequently utilized in empirical studies is the domestic or world interest rate. According to the mentioned study of Gacaner Atış and Saygılı (2014), in Turkish economy, there is a unidirectional causality from real interest rate to the share of the current account balance in GDP. Canıdemir et al. (2011) find that an increase in interest rate reduces current deficit in Turkey. In their study Esen et al. (2012) investigate the effects of a probable increase in the policy interest rate on current account deficit for Turkish economy. The findings of the study reveal that the credit channel is more dominant than the exchange rate channel in the period examined, therefore an increase in policy interest rate would reduce the current account deficit via the credit channel. According to the results of the panel data analysis made by Kesikoğlu et al. (2013) for 28 OECD countries, interest rates have a medium-term and low-level impact on the current account deficit. In their study Obstfeld and Rogoff (2001) empirically explore that countries with current account deficit tend to have a higher real interest rate. In their analysis on the OECD countries, they find that there is a highly significant negative relationship between current account surplus and domestic real interest rate.

\section{METHODOLOGY AND DATASET}

In Turkish economy there is a general opinion that the most important cause of current deficits is the foreign trade deficits. Thus it is observed that in Turkish economy current account balance and foreign trade balance statistics move considerably alike (see Fig. 1 and also Appendix 2). The production structure of Turkish manufacturing industry that is dependent on import of intermediate goods raises foreign trade deficits and hence current deficits through an increase in growth. From this viewpoint gross domestic product and foreign trade balance of Turkey is integrated to the empirical model in the study. On the other hand, there are two distinct approaches on the effects of domestic interest rates on current balance in the literature. Accordingly, an increase in domestic interest rates affects foreign trade and current account balance negatively by appreciation of domestic currency (i.e. decreasing nominal exchange rate -in direct quotation definition) through an increase in foreign capital inflows. On the other hand interest rates positively affect foreign trade and current account balance through reducing import demand by contracting consumption and hence credit demand. The final effect of an 
increase in interest rates on external balance would alter according to the extent of these two effects.

By frequently emphasizing the Harberger-Laursen-Metzler (HLM) effect, the relationship between international terms of trade and current balance is also underlined. By utilizing a Keynesian model, Harberger (1950) and Laursen and Metzler (1950) showed an exogenous increase in the terms of trade caused an improvement in trade balance of an open small economy. Accordingly an improvement in the terms of trade of a country would increase its current income, hence (under the assumption that marginal propensity to consume is less than unity) current consumption would increase less than current income. This in turn would increase personal savings and affect current balance positively (Bouakez and Kano, 2008). HLM hypothesis, in simplest terms, argues that positive (or negative) alterations in the terms of trade of any country, ceteris paribus, would cause positive (or negative) alterations in the balance of trade of the country (Yamak and Korkmaz, 2006).

Real exchange rates are also accepted as a crucial variable in explaining current balance. Besides the effects of real exchange rates on foreign trade and current account balance is still a more controversial topic. Depending on the appreciation of national currency or a higher increase in domestic inflation rate compared to trade partners, it is anticipated that an increase in real effective exchange rate would -ceteris paribus- decrease foreign trade competitiveness and hence affect foreign trade and current account balance negatively.

In the empirical part of the study, the relationships of the current account balance (CAB) with foreign trade balance (FTB), gross domestic product (GDP), terms of trade (TOT), domestic interest rate (INT) and real effective exchange rate (RER) in Turkish economy are analyzed for the 1994:Q1-2014:Q4 period. Explanations for the dataset are given in Appendix $1 .{ }^{11}$ CAB, FTB, GDP and TOT series are included to the analyses after they are corrected with the $\mathrm{X}-12$ (additive) method for seasonal effects. CAB, FTB and GDP series are taken as millions of USD. KPSS unit root test, Johansen Cointegration test, Fullymodified Ordinary Least Squares (FMOLS), Dynamic OLS (DOLS) and Canonical Cointegrating Regression (CCR) methods are used in order to examine the relationships between current account balance and other variables. Eviews 8 is used for the analyses.

\section{EMPIRICAL RESULTS AND DISCUSSION}

\subsection{Unit Root Test}

In a time series model it is necessary to test whether stochastic process varies depending on time or not, in other words whether it is stationary or not. If stochastic processes is constant (stationary) throughout the time, a model with a constant coefficient can be obtained by using past values of the series (Kutlar, 2005). In stationary series possible shocks would be temporary, the effect of the shock would decrease gradually and the series would turn back to its long-term average. On the contrary, there would not be a long-term average to be turned back after shocks for non-stationary series (Öztürk et al.,

\footnotetext{
${ }^{11}$ Time graphs of the variables are also given in Appendix 2, Appendix 3 and Appendix 4.
} 
2012). "A stochastic process is said to be stationary if its mean and variance are constant over time and the value of covariance between two time periods depends only on the distance or lag between the two periods and not on the actual time at which the covariance is computed" (Gujarati, 2004). If the series used in the analysis are not stationary, the reliability of the results becomes questionable due to the emergence of spurious regression problem in models and the lack of constant variance in time series (Hatırlı et al., 2008).

In order to determine a time series is stationary or not, the main method is the unit root tests. Therefore in the empirical analysis part of the study, at first the stationarity of the time series is tested with the KPSS unit root test (Kwiatkowski et al., 1992). Some studies show that the Dickey-Fuller tests have low power in distinguishing between the null and the alternative hypothesis. These studies suggest performing tests of the null hypothesis of mean stationarity against an alternative of a unit root in order to decide whether the time series data are stationary or integrated (Sukar and Hassan, 2001). Thus, KPSS unit root test uses Lagrange Multiplier (LM) statistic for testing the null hypothesis of the time series is stationary around a deterministic trend against the alternative hypothesis of nonstationary. In this regard we apply the KPSS unit root test to time series data. The results of the KPSS test are shown in Table 1.

Table 1: KPSS Unit Root Test Results

\begin{tabular}{|c|c|c|c|c|}
\hline \multirow[b]{2}{*}{ Variable } & \multicolumn{2}{|c|}{ Level } & \multicolumn{2}{|c|}{ First Difference } \\
\hline & Intercept & Trend and Intercept & Intercept & $\begin{array}{l}\text { Trend and } \\
\text { Intercept }\end{array}$ \\
\hline CAB & $1.094889 * * *[6]$ & $0.142610 *[5]$ & $0.046180[2]$ & 0.023812 [2] \\
\hline FTB & $1.088811 * * *[6]$ & $0.170566 * *[6]$ & $0.050171[1]$ & $0.027652[1]$ \\
\hline GDP & $1.096156 * * *[7]$ & $0.172277 * *[6]$ & $0.069544[2]$ & $0.063139[2]$ \\
\hline TOT & $1.178365 * * *[6]$ & $0.213883 * *[6]$ & $0.252868[2]$ & $0.041167[3]$ \\
\hline INT & $1.212764 * * *[6]$ & $0.147471 * *[3]$ & $0.281751[9]$ & $0.096274[10]$ \\
\hline RER & $1.186715^{* * *}[6]$ & $0.162479 * *[5]$ & 0.107484 [10] & $0.106138[10]$ \\
\hline \multicolumn{5}{|c|}{$\begin{array}{l}(* * *),\left({ }^{* *}\right) \text { and }\left({ }^{*}\right) \text { denotes rejection of the null hypothesis of "no unit root" (KPSS test) at the } 1 \%, 5 \% \text { and } 10 \% \\
\text { statistical significance level, respectively. The values in brackets indicate the optimal bandwidth chosen } \\
\text { automatically by Newey-West using Bartlett kernel. Asymptotic critical values (Kwiatkowski et al., } 1992, \text { Table } 1 \text { ) } \\
\text { for the models including intercept are } 0.739(1 \%), 0.463(5 \%), 0.347(10 \%) \text { and for the models including trend } \\
\text { and intercept are } 0.216(1 \%), 0.146(5 \%), 0.119(10 \%) .\end{array}$} \\
\hline
\end{tabular}

Table 1 shows the null hypothesis of "no unit root" for the variables is rejected in levels but cannot rejected in first differences for both models including intercept and models including trend and intercept by the KPSS test. According to the KPSS unit root test results, it is seen that all variables are not stationary in level but they are stationary in first differences.

\subsection{Johansen Cointegration Test}

If time series variables are non-stationary in their levels but stationary in first differences, they are integrated of order one. These variables may also be co-integrated if one or more linear combinations exist among them which are stationary. If these variables are cointegrated, then there is a stable long-run or equilibrium linear relationship among them 
(Lim and McAleer, 2001). In case of the series are co-integrated, it is concluded that they move together in the long term and level values of the variables can be used for the long run analysis. If the variables are more than two, it is possible to be more than one cointegrating vectors. In this context Johansen $(1988,1991)$ and Johansen and Juselius (1990) showed that there could be more than one co-integration relationship among variables with the cointegration test based on vector autoregressive (VAR) model. As all the variables are first-difference stationary (i.e. I(1)) in our empirical model, all variables will be included in the Johansen cointegration analysis. The optimal lag level for the unrestricted VAR model is determined as six where the variables in the model are in level values. ${ }^{12}$ The number of cointegrating relations according to the different cointegration models is given in Table 2 below.

Table 2: Selected ( 0.05 level)* Number of Cointegrating Relations by Cointegration Models

\begin{tabular}{cccccc}
\hline \multirow{2}{*}{$\begin{array}{c}\text { Data Trend } \\
\text { Test Type }\end{array}$} & $\begin{array}{c}\text { Model-1 } \\
\text { No Intercept } \\
\text { No Trend }\end{array}$ & $\begin{array}{c}\text { Model-2 } \\
\text { Intercept } \\
\text { No Trend }\end{array}$ & $\begin{array}{c}\text { Model-3 } \\
\text { Intercept } \\
\text { No Trend }\end{array}$ & $\begin{array}{c}\text { Model-4 } \\
\text { Intercept } \\
\text { and Trend }\end{array}$ & $\begin{array}{c}\text { Quadratic } \\
\text { Intercept } \\
\text { and Trend }\end{array}$ \\
\hline Trace Test & 2 & 1 & 1 & 1 & 1 \\
Max-Eigen Test & 1 & 1 & 1 & 1 & 1 \\
\hline *Criticaryyyyyyyyyyyyy
\end{tabular}

*Critical values (0.05 level) based on MacKinnon, Haug and Michelis (1999).

All models except Model-1 show that there is one cointegrating relation among variables. In this case it is important to choose the appropriate model. For this purpose, in order to simultaneously determine the cointegration rank and the deterministic components of the cointegration model, Pantula principle (Pantula, 1989) is applied for the models except Model-1 which shows different results for trace and max-eigen test. Results of the Pantula principle are given in Table 3.

Table 3: Model Determination According to the Pantula Principle by Cointegration Rank Test (Trace)

\begin{tabular}{lcccc}
\hline $\begin{array}{l}\text { Hypothesized No. of } \\
\text { cointegrating equation(s) }\end{array}$ & Model-2 & Model-3 & Model-4 & Model-5 \\
\hline None & 127.3289 & 103.6366 & 123.6951 & 109.5012 \\
& $(0.0006)^{*}$ & $(0.0128)^{*}$ & $(0.0197)^{*}$ & $(0.0358)^{*}$ \\
At most 1 & 74.55643 & 57.62134 & 77.67920 & 64.22736 \\
& $(0.0753)$ & $(0.3156)$ & $(0.2418)$ & $(0.3937)$ \\
\hline
\end{tabular}

\footnotetext{
${ }^{12}$ According to the VAR analysis with six lag, the inverse roots of the VAR model are found to take place within the unit circle (see Appendix 5). Autocorrelation problem is examined up to ten lag length with LM test and no autocorrelation is observed in the model. According to the White test results there is no heteroscedasticity problem in the model (see Appendix 6). CUSUM and CUSUM-Q structural change tests for the model also showed there is no structural change in the model, so there is no need to a dummy variable (see Appendix 7). These results show that VAR(6) model satisfies the stability conditions.
} 
*Denotes rejection of the hypothesis at the 0.05 level. Coefficients are the trace statistics. The values in brackets indicate the $p$-values (MacKinnon, Haug and Michelis, 1999).

Table 3 shows that for all models the null hypothesis of "no cointegration" is rejected whereas the null hypothesis of "at most 1 cointegration" cannot be rejected. On the other hand according to the Pantula principle, the null of existence of a cointegration cannot be rejected in first place by the Model-2. This result shows that the appropriate model for the Johansen cointegration analyses is Model-2 which assumes no deterministic trend in data and includes intercept (but no trend) in cointegration equation. Johansen cointegration test results for the Model- 2 are presented in Table 4 below. According to the Johansen test results, Trace and Max-Eigenvalue cointegration rank tests indicate one cointegrating equation at the 0.05 level.

Table 4: Johansen Cointegration Test Results

\begin{tabular}{|c|c|c|c|c|}
\hline \multicolumn{5}{|c|}{ Unrestricted Cointegration Rank Test (Trace) } \\
\hline Hypothesized & & Trace & 0.05 & \\
\hline No. of $C E(s)$ & Eigenvalue & Statistic & Critical Value & Prob.** \\
\hline None * & 0.491642 & 127.3289 & 103.8473 & 0.0006 \\
\hline At most 1 & 0.323352 & 74.55643 & 76.97277 & 0.0753 \\
\hline At most 2 & 0.181910 & 44.08937 & 54.07904 & 0.2843 \\
\hline At most 3 & 0.138578 & 28.42826 & 35.19275 & 0.2227 \\
\hline At most 4 & 0.125155 & 16.79298 & 20.26184 & 0.1404 \\
\hline At most 5 & 0.078346 & 6.363696 & 9.164546 & 0.1644 \\
\hline \multicolumn{5}{|c|}{ Unrestricted Cointegration Rank Test (Maximum Eigenvalue) } \\
\hline Hypothesized & & Max-Eigen & 0.05 & \\
\hline No. of CE(s) & Eigenvalue & Statistic & Critical Value & Prob.** \\
\hline None $*$ & 0.491642 & 52.77245 & 40.95680 & 0.0016 \\
\hline At most 1 & 0.323352 & 30.46706 & 34.80587 & 0.1506 \\
\hline At most 2 & 0.181910 & 15.66111 & 28.58808 & 0.7686 \\
\hline At most 3 & 0.138578 & 11.63528 & 22.29962 & 0.6903 \\
\hline At most 4 & 0.125155 & 10.42929 & 15.89210 & 0.2968 \\
\hline At most 5 & 0.078346 & 6.363696 & 9.164546 & 0.1644 \\
\hline
\end{tabular}

*Denotes rejection of the hypothesis at the 0.05 level. **MacKinnon-Haug-Michelis (1999) $p$-values.

\subsection{Long-Term Coefficients}

Depending on there is a cointegration relationship among variables it is possible to apply ordinary least squares (OLS) methods with the level values of the variables for long term coefficient estimations. In this context Fully Modified Ordinary Least Squares (FMOLS), Canonical Cointegrating Regression (CCR) and Dynamic Ordinary Least Squares (DOLS) methods are used in order to examine the relationships of current account balance (CAB) with foreign trade balance (FTB), gross domestic product (GDP), terms of trade (TOT), domestic interest rates (INT) and real effective exchange rate (RER) for Turkey. If all such alternative methods show similar results, confidence in their estimates increases. The estimated model is as follows:

$C A B_{t}=c_{t}+\alpha_{1} F T B_{t}+\alpha_{2} G D P_{t}+\alpha_{3} T O T_{t}+\alpha_{4} I N T+\alpha_{5} R E R+\varepsilon_{t}$ 
FMOLS, CCR and DOLS are single equation methods. These methods are designed to provide efficient estimates of cointegrating regressions. The FMOLS was originally introduced by Phillips and Hansen (1990). FMOLS estimation procedure assumes the existence of a single cointegrating vector (Phillips and Hansen, 1990). In order to eliminate the estimation problems caused by the long-run correlation between the cointegrating equation and the stochastic regressors innovations, this method employs a semiparametric correction. FMOLS method employs kernel estimators of the nuisance parameters that affect the asymptotic distribution of the OLS estimator. For asymptotic efficiency this method modifies least squares to account for serial correlation effects and test for the endogeneity in the regressors that result from the existence of a cointegrating relationship (Aljebrin, 2012; Risso et al., 2013). The resulting estimator is asymptotically unbiased and has fully efficient mixture normal asymptotics allowing for standard Wald tests using asymptotic Chi-square statistical inference (Belke and Czudaj, 2010).

CCR and DOLS estimators deal with the problem of second-order asymptotic bias arising from serial correlation and endogeneity, and together with FMOLS they are asymptotically equivalent and efficient (Risso et al., 2013). Park's (1992) Canonical Cointegrating Regression (CCR) is closely related to FMOLS, but instead employs stationary transformations of the data to obtain least squares estimates to remove the long run correlation between the cointegrating equation and stochastic regressors innovations (Belke and Czudaj, 2010). Like FMOLS, CCR estimates follow a mixture normal distribution which is free of non-scalar nuisance parameters and permits asymptotic Chi-square testing. Another simple approach to constructing an asymptotically efficient estimator that eliminates the feedback in the cointegrating system has been presented by Phillips and Loretan (1991), Saikkonen $(1991,1992)$ and Stock and Watson $(1993)$ which is termed as Dynamic OLS (DOLS). This method involves augmenting the cointegrating regression with lags and leads of the first differences of the regressors to correct for the endogeneity bias, so that the resulting cointegrating equation error term is orthogonal to the entire history of the stochastic regressor innovations (Belke and Czudaj, 2010; Eviews 8 User's Guide II, 2013; Vogelsang and Wagner, 2014). In DOLS procedure, one of the I(1) variables regresses on the other $I(1)$ variables, the $I(0)$ variables, and lags and leads of the firstdifferences of the $I(1)$ variables. The procedure includes the first-differenced variables to avoid small-sample bias resulting from correlation between the error term and the $I(1)$ variables. Standart hypothesis testing can then be done by using robust standart errors (Caporale and Chui, 1999). All these methods require tuning parameter choices. For FMOLS and CCR, a kernel function and a bandwidth have to be chosen for long run variance estimation. For DOLS the number of leads and lags has to be chosen and if the DOLS estimates are to be used for inference, a long run variance estimator -with an ensuing choice of kernel and bandwidth- is also required (Vogelsang and Wagner, 2014).

The results for the FMOLS, CCR and DOLS methods are given in Table 5 below. 
Table 5: Estimation of Long-Term Coefficients

\begin{tabular}{lccc}
\hline & FMOLS & CCR & DOLS \\
\hline FTB & $0.950^{* * *}$ & $0.950^{* * *}$ & $0.943^{* * *}$ \\
GDP & $(24.441)$ & $(24.085)$ & $(18.456)$ \\
& $0.017^{* *}$ & $0.016^{* *}$ & $0.015^{*}$ \\
TOT & $(2.054)$ & $(2.392)$ & $(1.727)$ \\
& $62.968^{* * *}$ & $59.052^{* * *}$ & $61.837^{* *}$ \\
INT & $(3.380)$ & $(3.173)$ & $(2.580)$ \\
& 3.607 & 1.745 & 5.938 \\
RER & $(0.826)$ & $(0.433)$ & $(0.931)$ \\
& -12.703 & -16.106 & -5.190 \\
Constant & $(-0.825)$ & $(-1.045)$ & $(-0.239)$ \\
& $-5237.2^{*}$ & $-4405.8 *$ & $-5825.6 * *$ \\
\hline
\end{tabular}

$\left({ }^{* *}\right),\left({ }^{* *}\right)$ and $(*)$ denotes $1 \%, 5 \%$ and $10 \%$ statistical significance level, respectively. Values in brackets indicate t-statistics. Cointegrating equation deterministic is selected as constant (level) parallel to the Model-2 determined by the Pantula principle for the Johansen cointegration test. Long run covariance estimate method is selected as Bartlett kernel using Newey-West automatic bandwidth (NW. automatic lag length=3) in FMOLS and CCR. Lead and Lag is determined by Schwarz Info Criterion automatically (Lead=0, Lag=0; max.=4) in DOLS.

Table 5 shows that both FMOLS, CCR and DOLS methods gives very close results for the estimated model. According to the results FTB, GDP, TOT and constant coefficients are statistically significant while INT and RER are not both in three methods. As expected FTB, TOT and INT affects CAB positively and RER affects CAB negatively ${ }^{13}$. Relationship between $C A B$ and GDP could be either positive or negative, and in our results GDP affects $C A B$ positively.

Findings of the analysis reveal that one unit rise in FTB affects $C A B$ positively almost as the increment in itself. This shows that CAB in Turkish economy is highly dependent to the FTB and they move together very closely. Rise in GDP also affects $C A B$ positively but the effect level is quite low both in three methods. If the domestic investments which substitute imports increase when GDP increases, the effect of GDP on CAB could be positive. According to DOLS results, one unit rise in domestic interest rates (INT) affects CAB positively about 6 million USD. Findings show that rise in domestic interest rates has a positive effect on $C A B$ but it is statistically insignificant and the effect level is low. According to CCR results, one unit rise in RER will affect CAB negatively about 16 million USD and this shows that RER does not have very high effect on CAB because RER generally does not change in high ratios in time. On the other hand coefficient of RER is also insignificant.

\footnotetext{
${ }^{13}$ If the national currency appreciates (i.e. decrease of nominal exchange rates in direct quotation definition) or domestic inflation is higher than trade partners inflation then the RER increases and in this case RER is expected to affect CAB and FTB negatively. In contrast, if the national currency depreciates (i.e. increase of nominal exchange rates in direct quotation definition) or domestic inflation is smaller than trade partners inflation then the RER decreases and in this case RER is expected to affect CAB and FTB positively.
} 
Another important result is about the TOT variable. All three methods show that TOT has a strong effect on $C A B$. According to the results one unit rise in TOT affects CAB positively about 60 million USD. This shows that depending on the production and export of hightech products Turkey's CAB could get better by time. In this respect the HLM hypothesis seems to be valid for Turkish economy which means increase of TOT affects FTB and therefore $C A B$ positively. At the same time this result is consistent with the positive effect of GDP on CAB. An improvement in the TOT of a country would increase its current income, therefore (under the assumption that marginal propensity to consume is less than unity) current consumption increases less than current income and in this situation personal savings increase and hence GDP effects CAB positively.

\section{CONCLUSION}

Since 2002, Turkish economy has achieved approximately an average annual real growth of $4.9 \%$. Despite real economic growth, one of the main problems in Turkish economy as in many emerging economies is increasing current account deficit. In Turkish economy, simple average value of the current account deficit-to-GDP ratio is $-5.06 \%$ in $2002-2014$ period and this shows that economic growth is financed without reducing the risk of the current account deficit, in other words it is financed by enduring the increase in the current account deficit. In this respect, it is important to examine the factors that affect the current account balance in Turkish economy.

In the study, the relationships of current account balance with foreign trade balance, gross domestic product, terms of trade, domestic interest rates and real effective exchange rates in Turkish economy are analyzed by using 1994:Q1-2014:Q4 quarterly data. KPSS unit root test has shown that all variables are stationary in their first differences. According to the all variables are stationary at first order, Johansen cointegration test was applied and one cointegration relationship is determined among variables in the model. As one cointegration is found among variables FMOLS, CCR and DOLS analysis were applied to determine long run relationships between current account balance and other variables.

Results of the analysis reveal that there is a strong relationship between current account balance and foreign trade balance in Turkish economy as expected. Gross domestic product and terms of trade are found as other statistically significant factors affecting current balance. On the other hand, effects of domestic interest rates and real effective exchange rates on current account balance are found statistically insignificant.

Effect of the gross domestic product on current balance is found quite low both in three methods. On the other hand all three methods show that terms of trade has a strong effect on current balance in Turkish economy. In this respect the Harberger-LaursenMetzler (HLM) hypothesis seems to be valid for Turkish economy. In this case increase of terms of trade is expected to affect foreign trade balance and therefore current balance positively and strongly in Turkish economy. This is also consistent with the positive effect of gross domestic product on current balance. This result indicates that depending on the production and export of high-tech products, Turkey's current account balance could get better by time. 
The positive effect of gross domestic product on current balance also reveals that if domestic investments increase with the increase of real income and substitute imports especially in high-tech products, this would generate a strong effect for Turkey for reducing foreign trade and hence current account deficits. Also by this way average price of Turkish exports might increase and average price of Turkish imports might decrease and thereby terms of trade would improve.

According to the results it is also assessed that increase in the domestic interest rates might improve current account balance via credit channel -by the decrease of consumption and import demand. In this regard, a reduction in interest rates through the Central Bank channel would increase directly both the imports and domestic prices by increasing the consumption demand; as a result this would bring about a negative effect on the current account balance. Therefore, even though a decline in domestic interest rates would decrease investment and financing costs, reduction in interest rates without taking remedial steps for the current account balance would increase the financial fragility and economic risks by increasing the current account deficit to unexpected levels. On the other hand, when the current account deficit and foreign trade deficit problems are considered together, the importance of the policies which aims to enhance the national competitiveness and to reduce dependence on intermediate goods in production would be understood once again.

\section{REFERENCES}

Aljebrin, M. A. (2012), "Labor Demand and Economic Growth in Saudi Arabia”, American Journal of Business and Management, 1(4), 271-277.

Aristovnik, A. (2008), "Short-Term Determinants of Current Account Deficits: Evidence from Eastern Europe and the Former Soviet Union", Eastern European Economics, 46(1), 24-42.

Baydur, C.M. (2012), "Kur İnse Ne Olur Çıksa Ne Olur, Bilmem Söylesem mi Söylemesem mi?", Finans Politik \& Ekonomik Yorumlar, 564, 5-10.

Bayraktutan, Y. and Demirtaş, I. (2011), “Gelişmekte Olan Ülkelerde Cari Açığın Belirleyicileri: Panel Veri Analizi", Kocaeli Üniversitesi Sosyal Bilimler Enstitüsü Dergisi, 2011/2(22), 1-28.

Belke, A. H. and Czudaj, R. (2010), "Is Euro Area money Demand (Still) Stable? Cointegrated VAR versus Single Equation Techniques", Ruhr Economic Papers, 171.

Bouakez, H. and Kano, T. (2008), "Terms of Trade and Current Account Fluctuations: The Harberger-Laursen-Metzler Effect Revisited", Journal of Macroeconomics, 30, 260-281. 
Canıdemir, S., Uslu, R., Ekici, D. and Yarat, M. (2011), "Türkiye'de Cari Açığın Yapısal ve Dönemsel Belirleyicileri”, Ekonomik Yaklaşım Kongreler Dizisi - VII, Gazi Üniversitesi İktisat Bölümü, Ankara.

Caporale, G. M. and Chui, M. K. F. (1999), Estimating Income and Price Elasticities of Trade in a Cointegration Framework", Review of International Economics, 7(2), 254-264.

Central Bank of the Republic of Turkey (2015a), Balance of Payment Statistics, http://www.tcmb.gov.tr, (Last access: 28.10.2015).

Central Bank of the Republic of Turkey (2015b), Electronic Data Delivery System, http://evds.tcmb.gov.tr/, (Last access: 28.10.2015).

Chinn, M. D. and Prasad, E. S. (2003), "Medium-term Determinants of Current Accounts in Industrial and Developing Countries: An Empirical Exploration", Journal of International Economics, 59(1), 47-76.

Corsetti, G. and Müller, G. J. (2006), "Twin Deficits: Squaring Theory, Evidence and Common Sense", Economic Policy, 21(48), 597-638.

Das, D. K. (2012), "Determinants of Current Account Imbalances in the Global Economy: A Dynamic Panel Analysis". MPRA Paper, 42419.

Edwards, S. (2001), “Does the Current Account Matter?”, NBER Working Paper, 8275.

Erbaykal, E. (2007), “Türkiye'de Ekonomik Büyüme ve Döviz Kuru Cari Açık Üzerinde Etkili midir? Bir Nedensellik Analizi", Zonguldak Karaelmas Üniversitesi Sosyal Bilimler Dergisi, 3(6), 81-88.

Erdoğan, S. and Bozkurt, H. (2009), "Türkiye'de Cari Açığın Belirleyicileri: MGARCH Modelleri ile Bir İnceleme", Maliye Finans Yazıları, 84, 135-172.

Erkılıç, E. (2006), Türkiye'de Cari Açığın Belirleyicileri, Uzmanlık Yeterlilik Tezi, T.C. Merkez Bankası - İstatistik Genel Müdürlüğü, Ankara.

Ertuna, Ö. (2007), "Aşırı Değerli TL ve Türkiye Ekonomisine Etkileri”, Muhasebe ve Finansman Dergisi, 35.

Esen, E., Yıldırım, Z. and Kostakoğlu, S. F. (2012), "Faiz Oranındaki Bir Artış Cari İşlemler Açığını Artırır Mı?”, Dumlupınar Üniversitesi Sosyal Bilimler Dergisi, 32(II), 215-227. 
Eurostat - European Commission Statistics (2015), Exchange Rates Statistics, http://epp.eurostat.ec.europa.eu/portal/page/portal/exchange_rates/data/database, (Last access: 28.10.2015).

EViews 8 User's Guide II (2013), IHS Global Inc.

FED - Board of Governors of the Federal Reserve System (2014), “Monetary Policy Report (February 11, 2014)", Washington D.C, http://www.federalreserve.gov/monetarypolicy/mpr_default.htm, (access: 10.8.2015).

Gacaner Atış, A. and Saygılı, F. (2014), “Türkiye'de Cari Açı̆̆ın Belirleyicilerinin Ampirik Analizi", Sosyoekonomi, 21(1), 87-103.

Göçer, ì. (2013), “Türkiye'de Cari Açığın Nedenleri, Finansman Kalitesi ve Sürdürülebilirliği: Ekonometrik Bir Analiz", Eskişehir Osmangazi Üniversitesi IiBF Dergisi, 8(1), 213-242.

Gujarati, D. N. (2004), Basic Econometrics, 4th Edition, New York: McGraw-Hill.

Gulzar, S., Feng, H. X. and Yajie, W. (2007), "The Current Account Balance of Pakistan 1972-2005: A Cointegration Analysis", Information Technology Journal, 6(5), 664-671.

Harberger, A. C. (1950), "Currency Depreciation, Income, and the Balance of Trade", Journal of Political Economy, 58(1), 47-60.

Hatırlı, S. A., Öztürk, E. and Aktaş, A. R. (2008), "Fındık Piyasasında Fiyat Geçirgenliğinin Analizi", Akdeniz Üniversitesi Ziraat Fakültesi Dergisi, 21(1), 139-143.

IMF - International Monetary Fund (2015), World Economic Outlook Database- October 2015, http://www.imf.org, (Last access: 28.10.2015).

Jawaid, S. T. and Raza, S. A. (2013), "Dynamics of Current Account Deficit: A Lesson from Pakistan", Transition Studies Review, 19(3), 357-366.

Johansen, S. (1988), "Statistical Analysis of Cointegration Vectors", Journal of Economic Dynamics and Control, 12(2-3), 231-254.

Johansen, S. (1991), "Estimation and Hypothesis Testing of Cointegration Vectors in Gaussian Vector Autoregressive Models", Econometrica, 59(6), 1551-1580.

Johansen, S. and Juselius, K. (1990), "Maximum Likelihood Estimation and Inference on Cointegration with Applications to the Demand for Money", Oxford Bulletin of Economics and Statistics, 52(2), 169-210. 
Kara, O. Çömlekçi, ì. And Kaya, V. (2012), "Turizm Gelirlerinin Çeşitli Makro Ekonomik Göstergeler ile İlişkisi: Türkiye Örneği (1992-2011)", Ekonomik ve Sosyal Araştırmalar Dergisi, 8(1), 75-100.

Kasman, A., Turgutlu, E. and Konyalı, G. (2005), "Cari Açık Büyümenin mi Aşırı Değerli TL'nin mi Sonucudur?", iktisat işletme ve Finans, 20(233), 88-98.

Kayıkçı, F. (2012), "Determinants of the Current Account Balance in Turkey: Vector Auto Regression (VAR) Approach", African Journal of Business Management, 6(17), 5725-5736.

Kesikoğlu, F.,Yıldııım, E. and Çeştepe, H. (2013), Cari Açığın Belirleyicileri: 28 OECD Ülkesi İçin Panel VAR Analizi", Ekonomik ve Sosyal Araştırmalar Dergisi, 9(2), 15-34.

Ketenci, N. (2010), "Major Determinants of Current Account in Russia”, Transition Studies Review, 17(4), 790-806.

Kutlar, A. (2005), Uygulamalı Ekonometri, 2. Baskı, Ankara: Nobel.

Kwiatkowski, D., Phillips, P.C.B., Schmidt, P. and Shin, Y. (1992), "Testing the Null Hypothesis of Stationary Against the Alternative of a Unit Root", Journal of Econometrics, 54, 159-178.

Laursen S. and Metzler, L. A. (1950), "Flexible Exchange Rates and the Theory of Employment", The Review of Economics and Statistics, 32(4), 281-299.

Lim, C. and McAleer, M. (2001), "Cointegration Analysis of Quarterly Tourism Demand by Hong Kong and Singapore for Australia", Applied Economics, 33, 1599-1619.

MacKinnon, J. G., Haug, A. A. and Michelis, L. (1999), "Numerical Distribution Functions of Likelihood Ratio Tests for Cointegration", Journal of Applied Econometrics, 14(5), 563-577.

Morgan Stanley, "Tales from the Emerging World", Commentary (December 3, 2013), http://www.morganstanley.com, (Access: 25.09.2014).

Obstfeld, M. and Rogoff, K. (2001), "The Six Major Puzzles in International Macroeconomics: Is There a Common Cause?", in NBER Macroeconomics Annual 2000, Vol. 15, (Eds: B.S. Bernanke and K. Rogoff), MIT Press, 339-412.

Oktar, S. and Dalyancı, L. (2012), "Dış Ticaret Hadlerinin Cari İşlemler Dengesi Üzerindeki Etkisi: Türkiye Örneği”, Marmara Üniversitesi i.i.B. Dergisi, 33(2), 1-18.

Otto, G. (2003), "Terms of Trade Shocks and the Balance of Trade: There is a HarbergerLaursen-Metzler Effect", Journal of International Money and Finance, 22, 155-184. 
Öztürk, M., Aras, O. N. and Kadı, O. S. (2012), “AB Borç Krizi ve Bunun Türk Dış Ticaretine Olan Etkileri”, Ekonomi Bilimleri Dergisi, 4(1), 77-89.

Pantula, S. G. (1989), "Testing for Unit Roots in Time Series Data", Econometric Theory, 5(2), 256-271.

Papadogonas, T. and Stournaras, Y. (2006), "Twin Deficits and Financial Integration in EU Member-States", Journal of Policy Modelling, 28, 595-602.

Park, J. Y. (1992), “Canonical Cointegrating Regressions”, Econometrica, 60(1), 119-143.

Peker, O. and Hotunluoğlu, H. (2009), "Türkiye'de Cari Açığın Nedenlerinin Ekonometrik Analiz", Atatürk Üniversitesi Iiktisadi ve Idari Bilimler Dergisi, 23(3), 221-237.

Phillips, P. C. B. and Hansen, B. E. (1990), "Statistical Inference in Instrumental Variables Regression with I(1) Processes", Review of Economic Studies, 57(1), 99-125.

Phillips, P. C. B. and Loretan, M. (1991), "Estimating Long-Run Economic Equilibria", Review of Economic Studies, 58(3), 407-436.

Risso, W. A., Punzo, L. F. and Carrera, E. J. S. (2013), "Economic Growth and Income Distribution in Mexico: A Cointegration Exercise", Economic Modelling, 35, 708-714.

Saikkonen, P. (1991), “Asymptotically Efficient Estimation of Cointegration Regressions”, Econometric Theory, 7(1), 1-21.

Saikkonen, P. (1992), "Estimation and Testing of Cointegrated Systems by an Autoregressive Approximation", Econometric Theory, 8(1), 1-27.

Seyidoğlu, H. (2009), Uluslararası Iktisat, İstanbul: Güzem Can.

Stock, J. H. and Watson, M. W. (1993), "A Simple Estimator of Cointegrating Vectors in Higher Order Integrated Systems", Econometrica, 61, 783-820.

Subaşat, T. (2010), “Türkiye'nin Cari Açık Sorunu: Nedenler ve Çözümler”, iktisat ve Toplum, 1, 26-34.

Sukar, A-H. and Hassan, S. (2001), "US Exports and Time-Varying Volatility of Real Exchange Rate", Global Finance Journal, 12, 109-119.

Tagliabue, G. (2005), "Co-Integrating Relationship Between Terms of Trade, Money And Current Account: The Italian Evidence", Operations Research and Decisions, 3-4, 99-111. 
Turkish Statistical Institute (2015a), Foreign Trade by Classification of Broad Economic Categories (in Statistics by Theme, Foreign Trade Statistics), http://www.turkstat.gov.tr/PreTablo.do?alt_id=1046, (Access: 15.09.2015).

Turkish Statistical Institute (2015b), GDP by Production Approach (in Main Statistics, National Accounts), http://www.tuik.gov.tr/UstMenu.do?metod=temelist, (Last access: 30.10.2015).

Turkish Statistical Institute (2015c), Foreign Trade Statistics Database, https://biruni.tuik.gov.tr/disticaretapp/menu_ing.zul, (Access: 20.11.2015).

Turkish Statistical Institute (2015d), Foreign Trade Indices Database (in Central Data Delivery System), http://tuikapp.tuik.gov.tr/medas, (Last access: 28.10.2015).

Uygur, E. (2001), “Krizden Krize Türkiye: 2000 Kasım ve 2001 Şubat Krizleri”, Türkiye Ekonomi Kurumu Tartışma Metni, No. 2001/1.

Uygur, E. (2012), “Türkiye'de Cari Açık Tartışması”, Türkiye Ekonomi Kurumu Tartışma Metni, No. 2012/25.

Uz, i. (2010), "Determinants of Current Account: The Relation Between Internal and External Balances in Turkey", Applied Econometrics and International Development, 10(2), 115-126.

Vogelsang, T. J. and Wagner, M. (2014), "Integrated Modified OLS Estimation and Fixed-b Inference for Cointegrating Regressions", Journal of Econometrics, 178, 741-760.

Yamak, R. and Korkmaz, A. (2006), "Harberger-Laursen-Metzler Etkisi: Literatür ve Türkiye Örneği”, Atatürk Üniversitesi Iktisadi ve Idari Bilimler Dergisi, 20(1), 57-69.

Yeldan, E. (2005), "Türkiye Ekonomisi'nde Dış Açık Sorunu ve Yapısal Nedenleri", Çalışma ve Toplum, No. 2005(4), 47-60. 


\section{Appendix 1: Explanations for the Dataset}

The data for Current Account Balance (CAB), Foreign Trade Balance (FTB) and domestic interest rates (INT) are gathered from the Electronic Data Delivery System (EDDS) of the Central Bank of the Republic of Turkey (CBRT). As a proxy of domestic interest rates, the weighted average of the overnight simple interest rate on the interbank market is used. The Terms of Trade (TOT) data (based on 2010=100, as USD) is obtained from the Foreign Trade Indices Database of Turkish Statistical Institute. Real Effective Exchange Rate (RER) data for Turkey (based on 2005=100 and deflated with the consumer price indices of 37 trading partner countries) are taken from the Eurostat (European Commission Statistics) database. Nominal GDP data for Turkey is taken from Eurostat in millions of Turkish Lira (TL) and converted to USD with the TL/USD exchange rate which is taken from the EDDS of CBRT. The data for all the variables belong to the 1994:Q1-2014:Q4 period.

Appendix 2: Current Account Balance (CAB) and Foreign Trade Balance (FTB) of Turkey (USD, million)

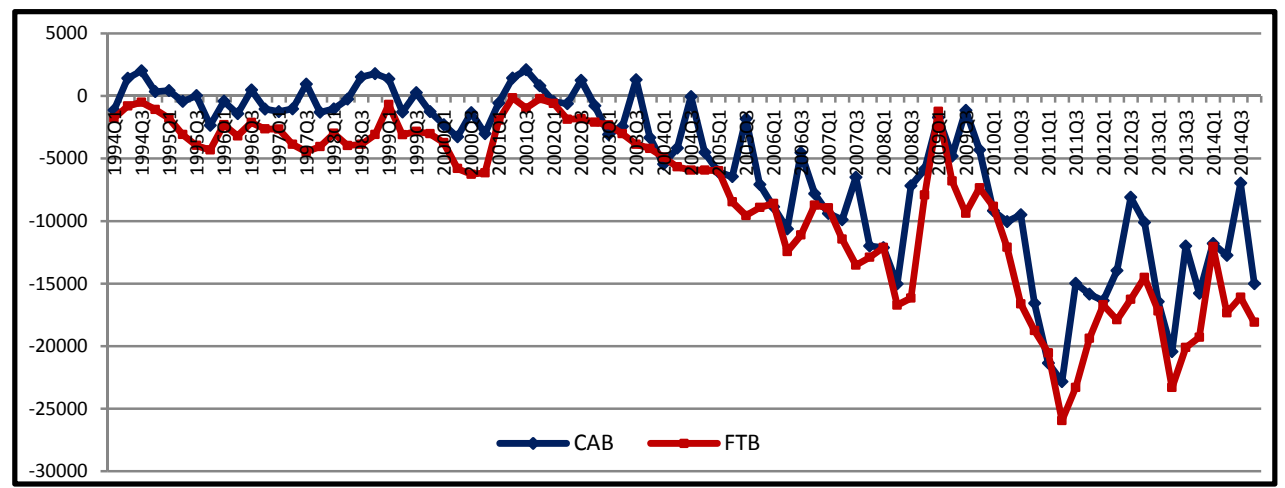

Source: Composed from the data of Central Bank of the Republic of Turkey (2015b). See Appendix, Explanations for the dataset.

Appendix 3: Terms of Trade (TOT), Domestic Interbank Overnight Interest Rate (INT) and Real Effective Exchange Rate (RER) of Turkey

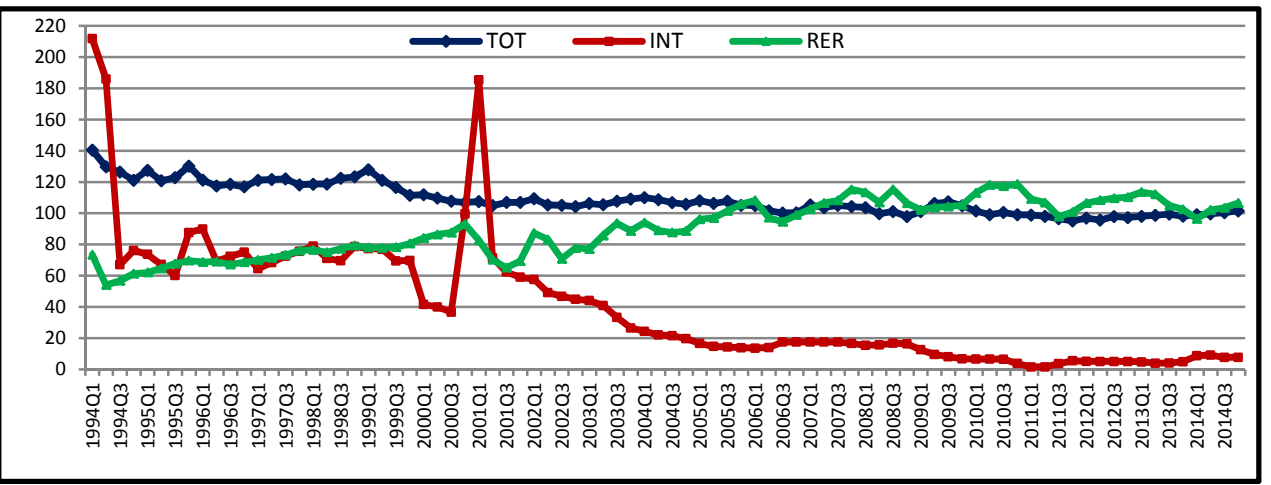

Source: Composed from the data of Central Bank of the Republic of Turkey (2015b), Eurostat (2015) and Turkish Statistical Institute (2015d). See Appendix, Explanations for the dataset. 
Appendix 4: Gross Domestic Product (GDP) of Turkey (USD, million)

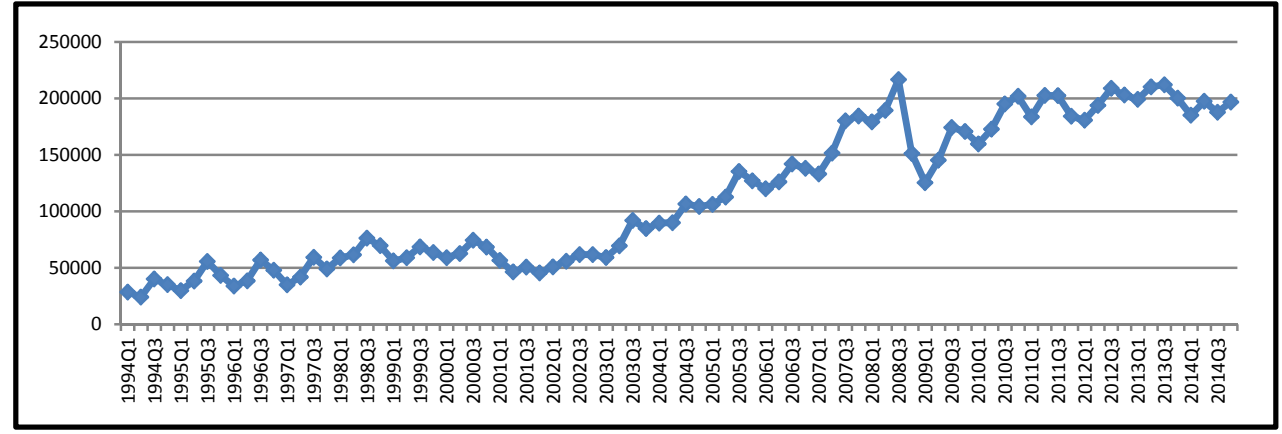

Source: Composed from the data of Eurostat (2015) and Central Bank of the Republic of Turkey (2015b). See Appendix, Explanations for the dataset.

\section{Appendix 5: Unit Circle Test Results}

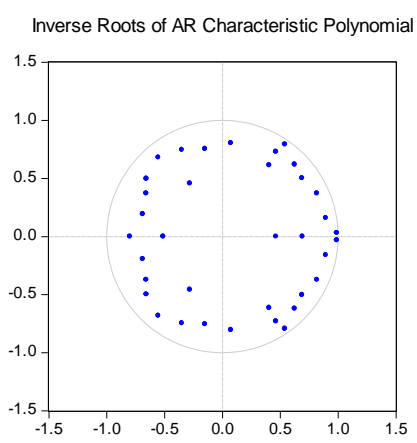

Appendix 6: Autocorrelation-LM and White's Heteroscedasticity Test Results

\begin{tabular}{ccc}
\hline & Autocorrelation-LM Test Results & \\
\hline Lags & LM-Stat & Prob. \\
1 & 40.43526 & 0.2808 \\
2 & 44.69465 & 0.1517 \\
3 & 39.96362 & 0.2984 \\
4 & 34.05960 & 0.5612 \\
5 & 37.20517 & 0.4134 \\
6 & 36.78804 & 0.4322 \\
7 & 33.60843 & 0.5829 \\
8 & 41.05279 & 0.2587 \\
9 & 41.40549 & 0.2465 \\
10 & 36.36400 & 0.4517 \\
\hline & White's Heteroscedasticity Test Results & \\
\hline Chi-sq & Df & 0.2116 \\
\hline
\end{tabular}

Note: VAR lag order is 6. 
Appendix 7: CUSUM \& CUSUM-Q Structural Change Test Results

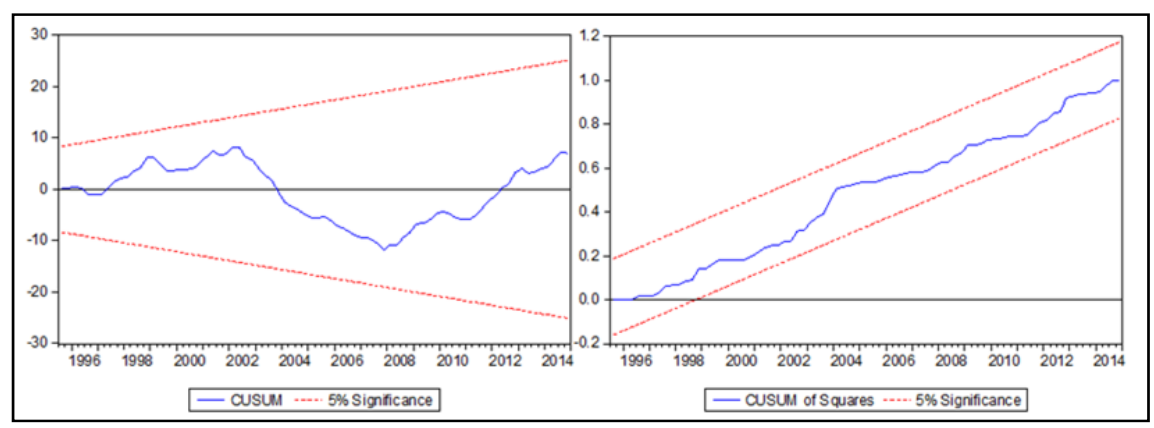

